\begin{tabular}{ccc}
\hline International Journal of Advanced Geosciences, $7(1)(2019) 74-84$ \\
SPC & Website: www.sciencepubco.com/index.php/IJAG \\
Research paper & Intional Journal of Advanced Geosciences \\
\hline
\end{tabular}

\title{
Major structural elements and petrophysical properties of the Miocene section, "xyz field", western shallow offshore depobelt, Niger delta
}

\author{
Ajibade M. A. ${ }^{1 *}$, Ajibade Adekola ${ }^{2}$, M. T. Olowokere ${ }^{3}$ \\ ${ }^{1}$ Department of Physical Science, Ondo State University of Science and Technology, Okitipupa, Ondo-State, Nigeria \\ ${ }^{2}$ Department of Geology, Obafemi Awolowo University, Ile Ife, Osun-State, Nigeria \\ *Corresponding author E-mail:
}

\begin{abstract}
$\mathrm{R} 1, \mathrm{R} 2, \mathrm{R} 3$, and F. reservoir units were identified in the XYZ field. The reservoirs are within the Oil proven fault block and F reservoir is located on the footwall structure of the second synthetic fault with similar structural characteristics. The faulting in the XYZ field resulted in a downward movement of the XYZ Discovery relative to the XYZ prospects. The structural development process of the field was a syn-sedimentary. This explains why the XYZ-1 penetration in the footwall of the synthetic found oil-in F sand. However, petrophysical results show that the reservoirs of interests have good petrophysical properties with minimum porosity of 0.1 and maximum water saturation of 0.7. The discoveries by the XYZ-1 well prove the existence of a working hydrocarbon source and charge system. However the distribution pattern of the discovered hydrocarbons is not yet understood.
\end{abstract}

Keywords: Hydrocarbon-Bearing Reservoirs; Lithology; Reservoir Property; Sand Unit and Prospect.

\section{Introduction}

The objective was to identify hydrocarbon-bearing reservoirs, determine their properties, fluid types and reserve sizes. It also included mapping of upside potentials within the "XYZ Field".

Details of the scope of work carried out include formation evaluation of the field for the purposes of determining the properties of all hydrocarbon-bearing reservoirs; carry out horizon and fault seismic interpretation and generate reservoir top maps for all the identified hydrocarbon-bearing reservoirs; correlate XYZ-1 to three nearby wells - AY-1, YY-1 and SY-1; compute the field reserves figure for each of the hydrocarbon-bearing sands.

\subsection{Location of the study area}

"XYZ" field is situated offshore in water depths ranging between $23 \mathrm{ft}$ and $27 \mathrm{ft}$ and is located south of the present day coastline of Ondo State (Figure 1).

The field was discovered in 1986 following the drilling and testing of XYZ-1 exploratory well. The discovery has not been appraised neither has it been put into production till date due to the marginal economic value ascribed to the field. The closest producing fields are the AY, YY and SY (Figure 2). 


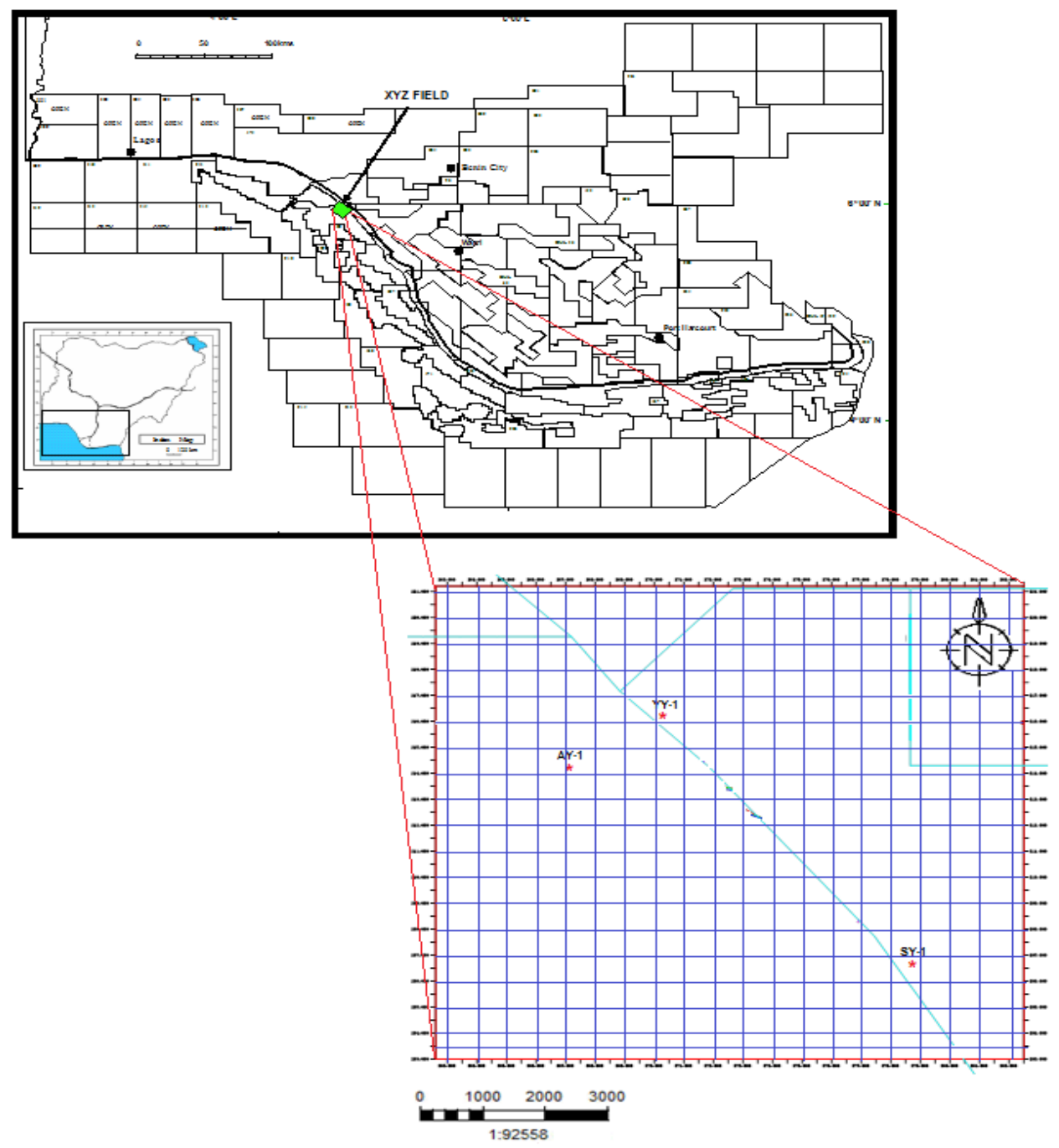

Fig. 1: Map of the Niger Delta Showing the Location of "XYZ" Field.

\section{Geology of the study Niger delta and the study area}

\subsection{Stratigraphy}

Following the opening of the South Atlantic, vast quantities of clastic sediments were poured into the delta giving rise to three main rock units which are partially time equivalents and were deposited as prograded wedges. The three major lithostratigraphic units defined in the Niger Delta include from youngest to oldest include Benin, Akata and Agbada Formations (Figure 2).The type sections of these formations are described in Short and Stäuble (1967) and summarized in a variety of papers (e.g. Avbobvo, 1978; Doust and Omatsola, 1990; Kulke, 1995).

The three stratigraphy units in the Niger-Delta region are:

The uppermost unit, the Benin Formation, comprises continental/fluviatile and back-swamp deposits up to $2500 \mathrm{~m}$ thick.

These are underlain by the Agbada Formation of paralic, brackish to marine, coastal and fluvio-marine deposits, organized into coarsening upwards 'offlap' cycles. The sands in this Formation constitute the major reservoirs for the hydrocarbons found in the Delta.

The underlying Akata Formation comprises up to $6500 \mathrm{~m}$ of marine pro-delta clays. Shales of the Akata Formation are overpressured and have deformed in response to delta progradation. These shales facilitate regional decollement for updip extension and downdip compression. Shales of the Akata Formation constitute a world-class source rock. Deepwater turbidite sands also exist within this formation. Figure 3 shows the schematic cross section of the Niger-Delta. 


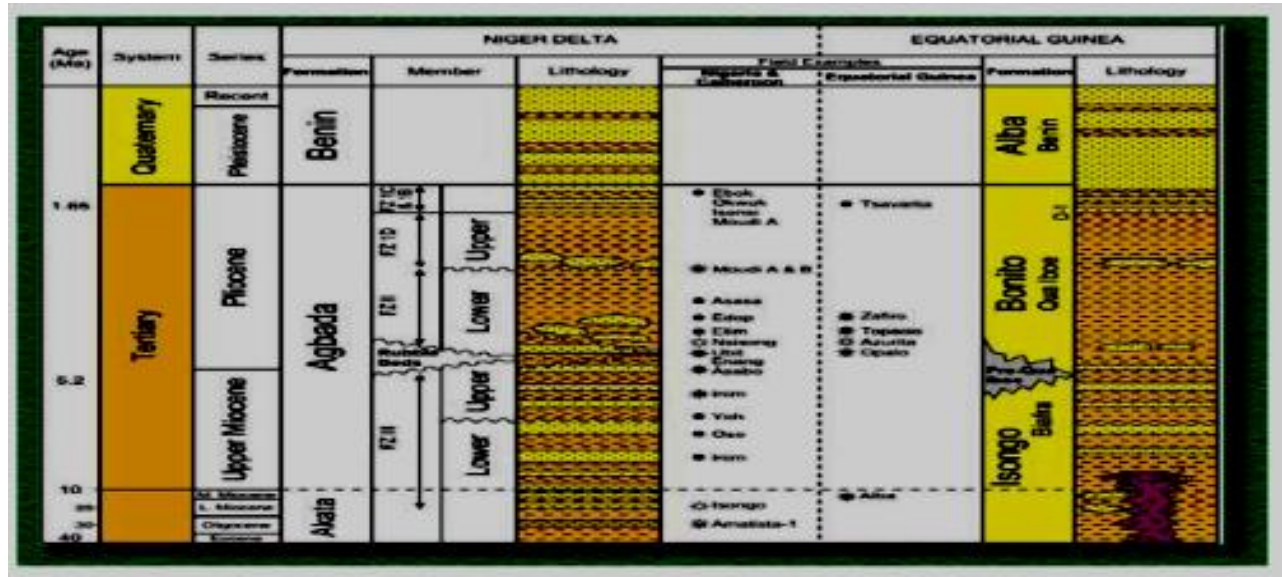

Fig. 2: Schematic Sections of Niger Delta Showing Major Formations.

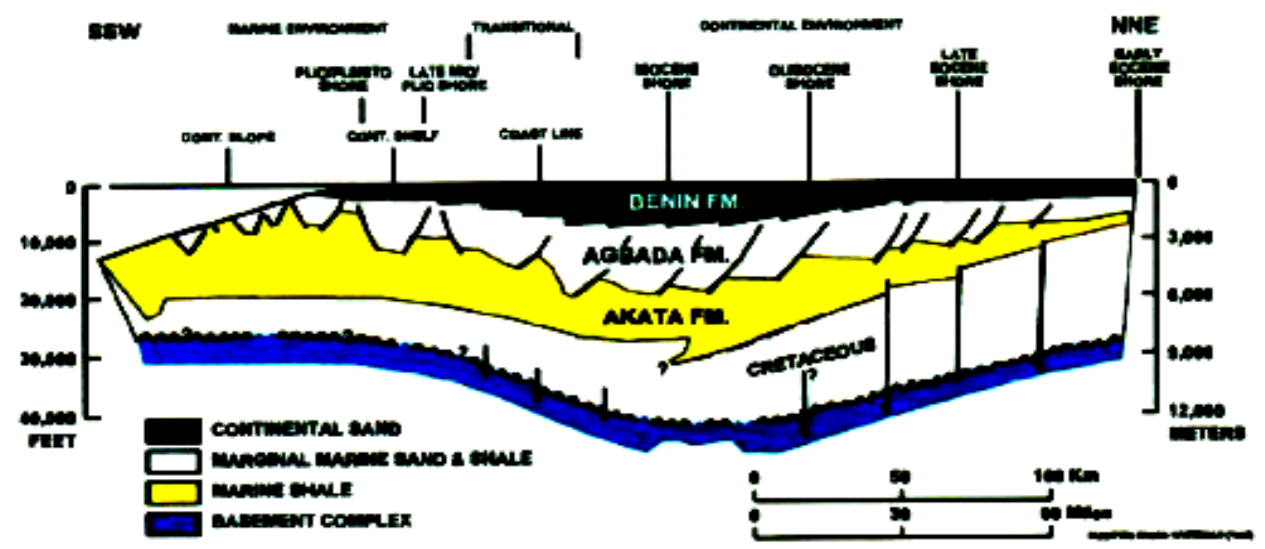

Fig. 3: Schematic Sections of Niger Delta Showing Major Formations.

The Niger Delta's main structural element consists of extensional growth faults on local and regional basis both on the land and shallow offshore region, which can be defined as synthetic (same direction as regional dip) or antithetic (opposite to regional dip). Further offshore and down-dip in the Delta, especially in the deep-water region, the major structural element consists of compressional folds associated with thrust faults. Figure 4 illustrates the main types of extensional faults. Examples of Niger Delta oil field structures and associated trap types. Modified from Doust and Omatsola (1990) and Stacher (1995). The XYZ prospect is a gently plunging NNW trending anticline separated in several elongate fault blocks by crestal extensional faulting. Figure 5 shows the regional fault system in the XYZ area.

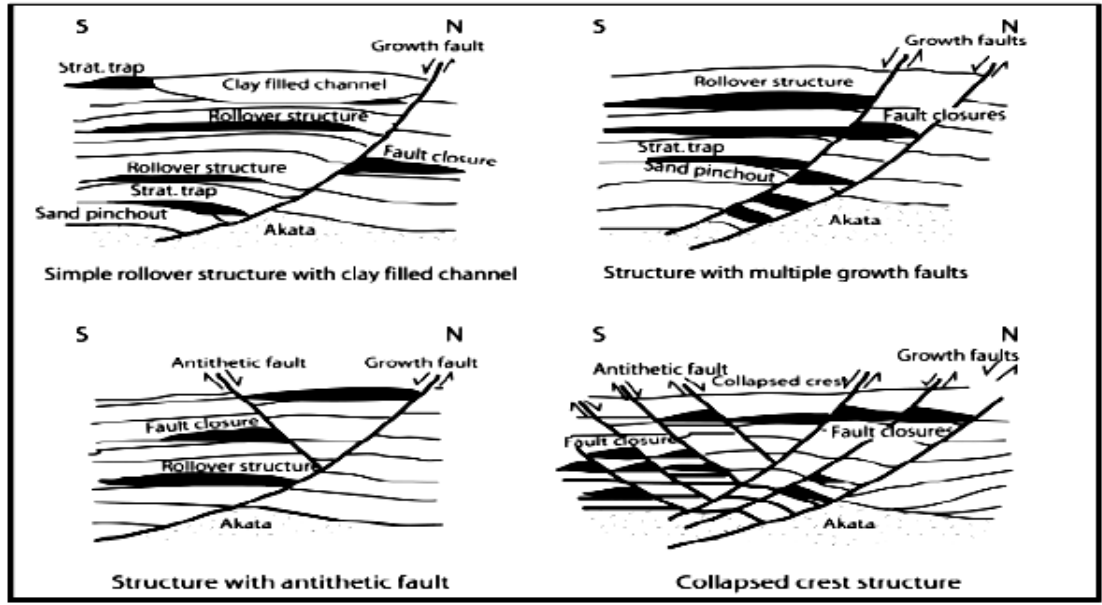

Fig. 4: The Main Types of Extensional Faults.

\subsection{Structural framework}

A younger Cenozoic Delta complex is notable for its development of "growth faults" which have produced the traps for its oil and gas fields. Growth faults are not present in the two earlier delta complexes, a factor which may partially explain their lack of prospectivity. They are called growth faults because they are active during the deposition of the sediments which they intersect. They are commonly cuspate in plain view, are steep-sided near the surface and flatten out to parallel bedding with depth. They frequently have a "roll-over" anticline with four-way closure on the downthrown side of the fault and antithetic faulting in the downthrown block. They are of limited length. 
The delta is cut by a homogenous sequence of down-to-the-basin faults trending north-west and south-east, similar in length and remarkably equidistant from each other. The coincidence of movement on the faults and the growth of the anticlines as the sediment was deposited resulted in ideal conditions for subsequent entrapment of hydrocarbons.

Oil and gas are found on the upthrow side of the main fault and in the anticlinal structure on the downthrown side of the fault. Numerous subordinate traps are formed by the antithetic faults affecting the rollover anticline. In addition, the shales associated with the rollover faults are commonly over-pressured and diapiric, adding to structural development in the overburden and increasing the seal on faults.

\section{Method of data Interpretation}

\subsection{Available data}

The following data were made available for this evaluation:-

1) Approximately $155 \mathrm{~km}^{2}$ of 16 -bit $3 \mathrm{D}$ migrated seismic data in $\mathrm{SEG}$ ' $\mathrm{Y}$ ' format.

2) Well data (Log curves and header information) for AY-1 well.

3) Digital log curve data for XYZ-1 in LAS format and paper composite log for AY-1 and SY-1.

\subsection{Log digitization}

Digital data was available for XYZ-1, however only paper composite logs were provided for the three adjourning wells. The paper logs were scanned and digitized to make room for evaluation on the workstation. These wells were used for correlation of the reservoir sands to improve the understanding of the regional distribution of the sands and their fluid content.

\subsection{Data interpretation}

\subsubsection{Seismic interpretation}

The available 3D seismic, restack time migration (PSTM) volume has already been interpreted by Schlumberger using Petrel software, in Schumberger work station. The interpreted seismic was map in time and then converted to depth by depth conversion process using XYZ-1 well check shot data. The 3D volume covers an area of $53 \mathrm{Sq} . \mathrm{km}$ with data covering the entire XYZ concession. Fault segments were mapped along the seismic section and correlated. Within the area of interest, the faults have the same trend (NW-SE and dipping northeast). The drilled wells penetrated two fault blocks at different depths. From the seismic interpretation, it was observed that reservoir sands, D and $\mathrm{F}$ are on the same fault compartment.

The available check-shot data was also loaded into petrel data base and this formed the basis for a seismic-well tie. The hydrocarbon bearing reservoirs of interest were posted with the seismic display to guide the time mapping. Four hydrocarbon bearing reservoirs were mapped and time maps were generated. The remaining maps were generated from these four maps based on their closeness to mapped reservoirs.

\subsubsection{Well correlation and cross section}

Well correlation was done in the field because only one well has been drilled. However a pseudo well, XYZ-1 was loaded into 3D geological model and the expected sand tops on the reservoirs of interest were delineated. The identified hydrocarbon bearing sands were subsequently mapped and depth structure maps were generated for each level. Geological cross-section was draw putting the sand of interest and the proposed XYZ-1 on the section in other to establish the structural trend of each of the reservoirs, as a guided for the well placement.

Ten key seismic horizons corresponding to the hydrocarbon-bearing zones which were calibrated from the Time/Depth data provided for the XYZ-1 well were mapped. Consistent attributes were carried for every surface mapped. All horizon time maps were depth converted using an initial velocity model generated from available TZ data for XYZ-1 well.

The depth-converted horizon using the velocity model created was used to generate the first initial depth map. A final depth grid that is consistent with the well impact points was generated after computing the error grid and subtracting that from the initial depth grid. Contact information obtained from the petrophysical interpretation was posted on the final map. Gas accumulations were colour-filled in green, while filled by oil were coloured red while areas filled with condensate and all prospects were colour filled in yellow.

\subsubsection{Petrophysics data analysis}

Porosity Evaluation: Porosities were generated using the Sonic and Neutron-Density Method. R of $1.0 \mathrm{~g} / \mathrm{cc}$ for water, $0.80 \mathrm{~g} / \mathrm{cc}$ for oil and $0.65 \mathrm{~g} / \mathrm{cc}$ for gas were used for porosity in computation.

Neutron Density cross-plots and histograms were generated in order to determine the table of constants (Table 7) which contain GR shale, GR clean, etc.

Hydrocarbon Saturation: The Indonesian saturation equation was employed in generating the water saturations used in this study. The reservoir property and summation (Table 7) summarizes the conclusion of this study. This shows the average net pay, porosity and saturation values for all the wells.

\section{Results and discussion}

The XYZ field is situated between the bifurcated regional "AY-SY" NW-SE fault systems in the western Shallow offshore Niger Delta Depobelt. The seismic reveals evidence of a general shallowing of the tertiary Niger Delta towards the North West (Okitipupa High). The hydrocarbon accumulations encountered are trapped in hanging wall sands spanning three major compartments south to north defined by the bifurcation. The shallow levels (R1, R2 \& R3) indicate traps that are situated in the most southerly compartment and correlatable with AY-1. The R sands have a fault cut at the bottom of R3 sand (Figure $2 \& 3$ ). 


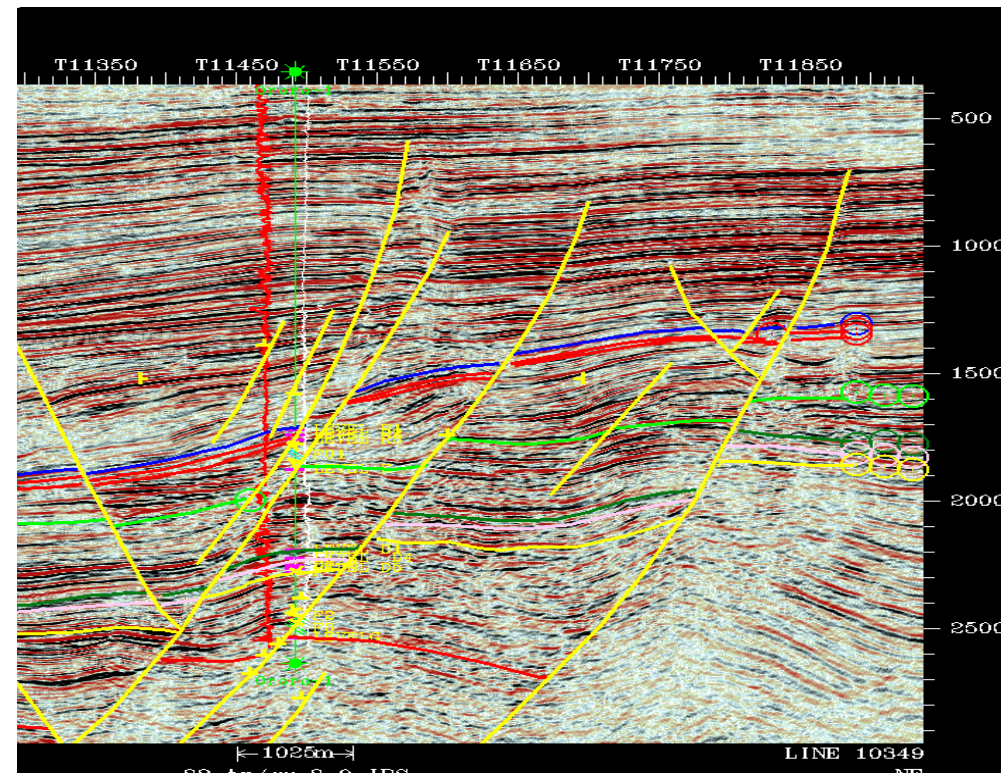

Fig. 2: Interpreted Seismic Section from Dip Line through XYZ -1 Well.

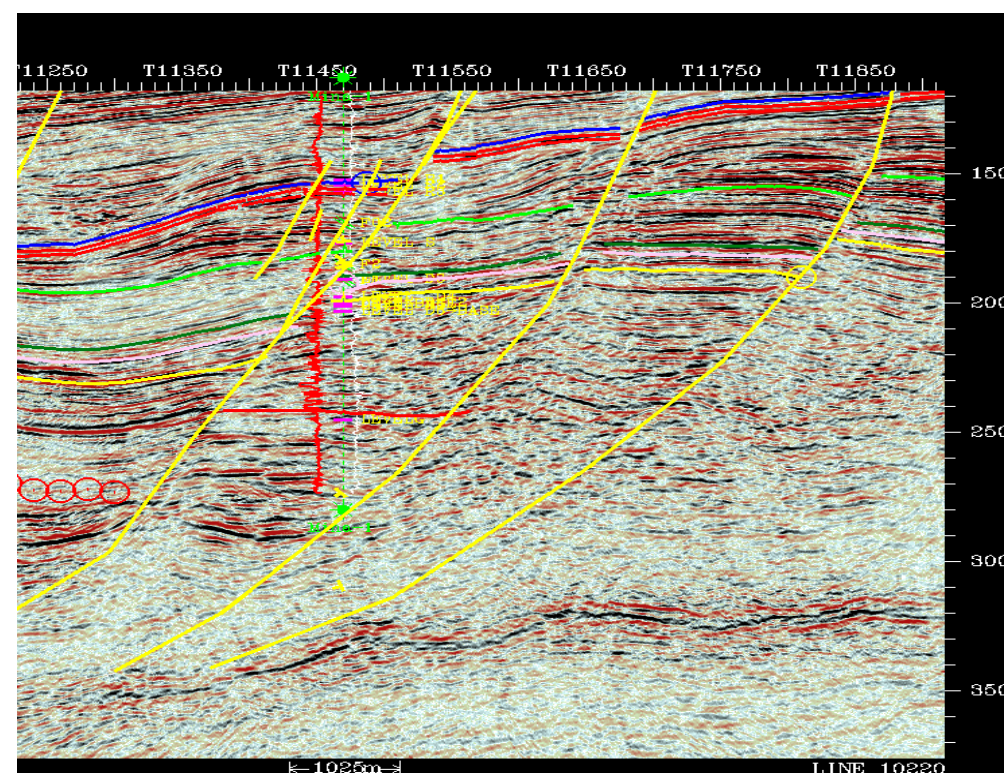

Fig. 3: Interpreted Seismic Section from Dip Line through AY-1 Well.

The XYZ structure is part of the AY-SY regional anticlinal system having faults trending NW-SE direction. This is typical of the western section of the Shallow Offshore Depobelt (Figure 3).

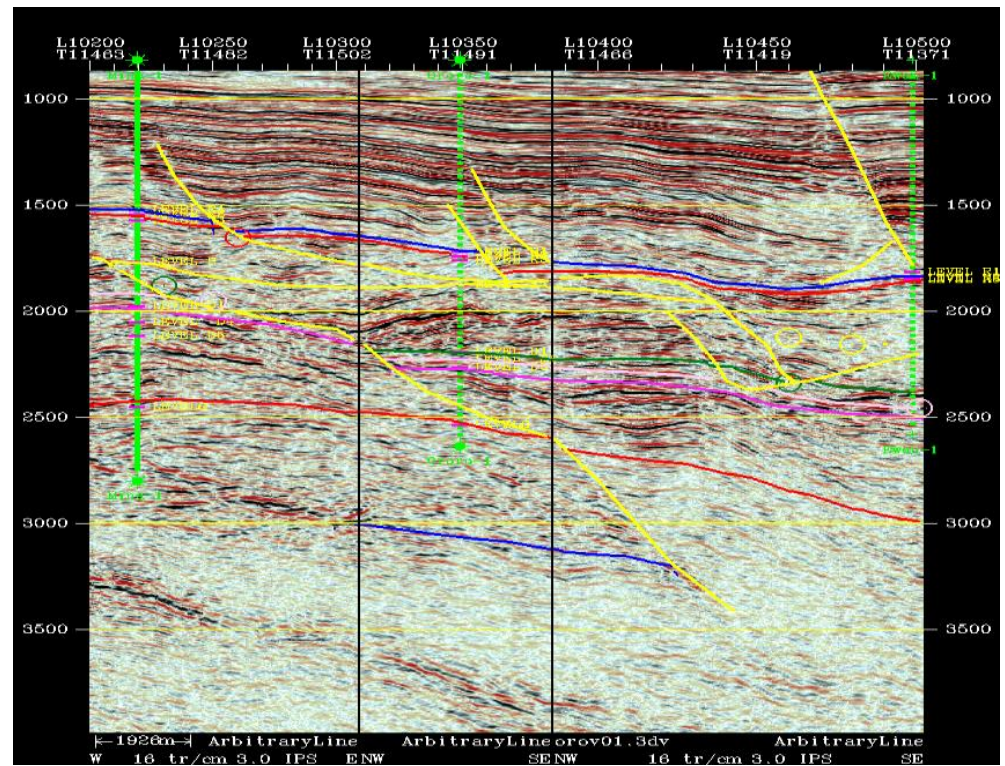

Fig. 4: Interpreted Seismic Section from Dip Line through AY-1, XYZ -1 and SY-1 Wells Litho-Stratigraphy \& Correlation. 
The XYZ -1 well penetrated continental sands of Benin formation and the multiple condensed paralic lithofacies sequence of the Agbada Formation. The Agbada consist of well-developed amplified sand bodies annotated down hole as R, S, D, F and G sands. The sands are capped by competent shale breaks of high sealing capabilities.

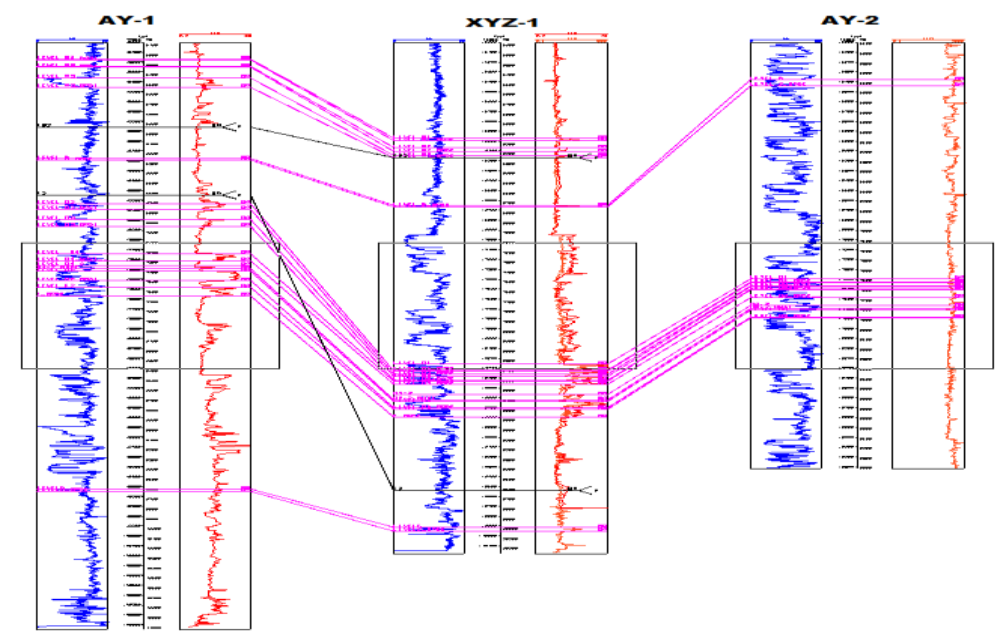

Fig. 5: Litho-Stratigraphic Cross-Section along AY-1, XYZ -1 and SY-1.

Based on biostratigraphic analysis and geological core description and paleoenvironmental analysis of XYZ-1 well, the stratigraphical interval investigated suggests that deposition occurred most likely in a delta plain setting. Conclusions drawn from the environment of deposition and correlation indicate that reservoir sands are expected to be continuous across the entire Field. Sediments of the paralic sequence encountered were possibly deposited during the Late Miocene to Middle Pliocene times.

Table 7: Table Of Petrophysical Properties from XYZ-1 Well

\begin{tabular}{|c|c|c|c|c|c|c|c|c|c|c|c|c|c|c|c|}
\hline $\begin{array}{l}\text { Petro } \\
\text { San } \\
\text { d }\end{array}$ & $\begin{array}{l}\text { nysical P } \\
\text { Top } \\
\text { Depth }\end{array}$ & $\begin{array}{l}\text { rties of } y \\
\text { Bot } \\
\text { Depth }\end{array}$ & $\begin{array}{l}-1 \\
\text { Top } \\
\text { Depth }\end{array}$ & $\begin{array}{l}\text { Bot } \\
\text { Depth }\end{array}$ & $\begin{array}{l}\text { Top- } \\
\text { Pay } \\
\end{array}$ & $\begin{array}{l}\text { Bot } \\
\text { Pay }\end{array}$ & $\begin{array}{l}\text { Top- } \\
\text { Pay } \\
\end{array}$ & $\begin{array}{l}\text { Bot } \\
\text { Pay }\end{array}$ & Gross & Net & Net & $\begin{array}{l}\text { NT } \\
\text { G }\end{array}$ & $\Phi$ & $\mathrm{Sw}$ & $\begin{array}{l}\text { Shal } \\
\mathrm{e}\end{array}$ \\
\hline & MD & MD & TVDSS & TVDSS & MD & MD & $\begin{array}{l}\text { TVDS } \\
\mathrm{S}\end{array}$ & $\begin{array}{l}\text { TVDS } \\
\mathrm{S}\end{array}$ & $\begin{array}{l}\text { Inter- } \\
\text { val }\end{array}$ & Pay & Res & & & & \\
\hline & (ft) & (ft) & (ft) & (ft) & (ft) & (ft) & (ft) & (ft) & (ft) & $(\mathrm{ft})$ & $(\mathrm{ft})$ & (frac & (frac & (frac & (frac \\
\hline $\begin{array}{l}\text { NN } \\
5\end{array}$ & 4983 & 5003.5 & -4912.6 & -4933.1 & $\begin{array}{l}4991.0 \\
0\end{array}$ & 4997 & $\begin{array}{l}4920.6 \\
0\end{array}$ & $\begin{array}{l}- \\
4926.6\end{array}$ & 20.50 & $\begin{array}{l}4.5 \\
0\end{array}$ & $\begin{array}{l}12.9 \\
2\end{array}$ & 0.63 & $\begin{array}{l}0.20 \\
7\end{array}$ & $\begin{array}{l}0.53 \\
6\end{array}$ & 0.37 \\
\hline R1 & 6041 & 6066 & -5970.6 & -5995.6 & $\begin{array}{l}6061.5 \\
0\end{array}$ & 6064.5 & $\begin{array}{l}- \\
5991.1 \\
0\end{array}$ & $\begin{array}{l}- \\
5994.1\end{array}$ & 25.00 & $\begin{array}{l}3.5 \\
0\end{array}$ & $\begin{array}{l}19.0 \\
0\end{array}$ & 0.76 & $\begin{array}{l}0.14 \\
7\end{array}$ & $\begin{array}{l}0.42 \\
5\end{array}$ & 0.24 \\
\hline $\mathrm{R} 2$ & 6130.5 & 6176 & -6060.1 & -6105.6 & $\begin{array}{l}6138.0 \\
0\end{array}$ & 6165.5 & $\begin{array}{l}- \\
6067.6 \\
0\end{array}$ & $\begin{array}{l}- \\
6095.1\end{array}$ & 45.50 & $\begin{array}{l}5.5 \\
0\end{array}$ & $\begin{array}{l}25.5 \\
0\end{array}$ & 0.55 & $\begin{array}{l}0.18 \\
1\end{array}$ & $\begin{array}{l}0.58 \\
3\end{array}$ & 0.45 \\
\hline R3 & 6214.5 & 6234 & -6144.1 & -6163.6 & $\begin{array}{l}6220.5 \\
0\end{array}$ & 6228 & $\begin{array}{l}- \\
6150.1 \\
0\end{array}$ & $\begin{array}{l}- \\
6157.6\end{array}$ & 19.50 & $\begin{array}{l}8.0 \\
0\end{array}$ & $\begin{array}{l}13.7 \\
0\end{array}$ & 0.70 & $\begin{array}{l}0.18 \\
4\end{array}$ & $\begin{array}{l}0.53 \\
5\end{array}$ & 0.30 \\
\hline $\mathrm{F}$ & 8789.5 & 8869 & -8719.1 & -8798.6 & 8797.5 & 8850.5 & $\begin{array}{l}- \\
8727.1 \\
0\end{array}$ & $\begin{array}{l}- \\
8780.1\end{array}$ & 79.50 & $\begin{array}{l}11 . \\
5\end{array}$ & $\begin{array}{l}35.8 \\
0\end{array}$ & 0.45 & $\begin{array}{l}0.17 \\
4\end{array}$ & $\begin{array}{l}0.46 \\
4\end{array}$ & 0.55 \\
\hline
\end{tabular}

\subsection{Reservoirs mapped}

R Sands

This level is subdivided into R1, R2 and R3.

R1 Sand

This reservoir is a shaly, low resistivity sand with a gross thickness of $25 \mathrm{ft}$ (Figure 9) Other petrophysical parameters calculated are as follows:-

R1 Top is 5970.1ft (TVDSS) while R1 Base is 5995.6ft (TVDSS); Gross Thickness, Net Res Thickness and Net Pay Thickness are 25ft., $20 \mathrm{ft}$., and $3.5 \mathrm{ft}$. respectively. Average Porosity, Average Water Saturation and Net-to-Gross ratio are 15\%, $43 \%$ and 0.76 respectively.The depth map (Figure 10.0) shows that R1 is in the most southerly compartment and from correlation; it extends to AY-1. The main $\mathrm{XYZ}$ compartment shows the possibility of a hanging wall prospect. 


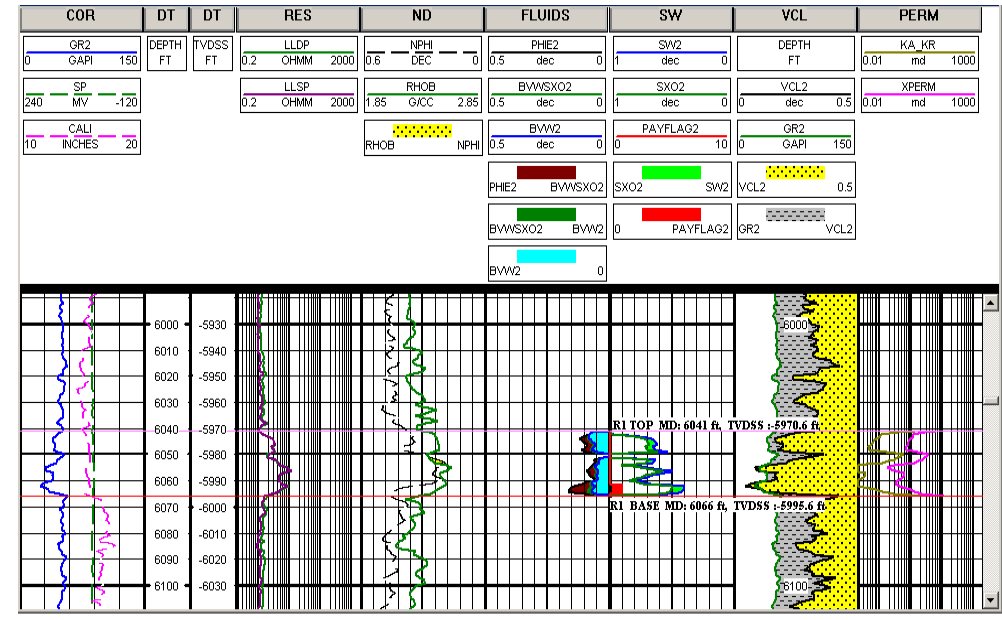

Fig. 9: Log Plot From R1 SAND.

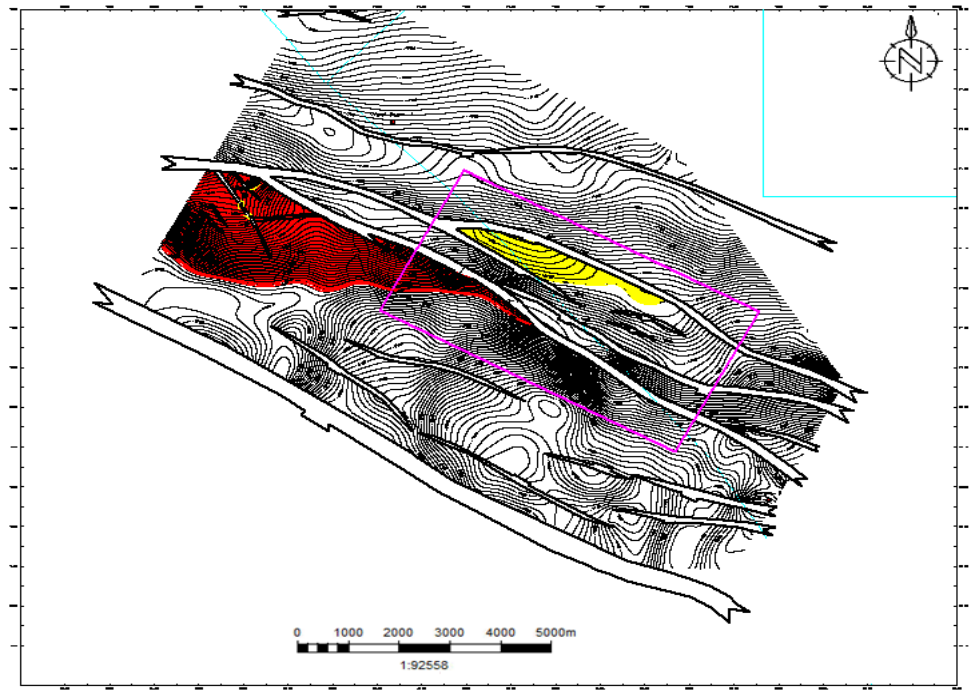

Fig. 10: R1 Sand Depth Structural Map.

R2 Sand

This is a very shaly reservoir with a low resistivity and a gross thickness of $45.5 \mathrm{ft}$. The GR curve indicates extremely shaly sand but the caliper curve coincides with the resistivity with which the tops and base of the reservoir are defined (Figure 11). This reservoir contains oil with other petrophysical parameters calculated being:-

R2 Top is 6060.1ft (TVDSS) while R2 Base is 6105.6ft (TVDSS); Gross Thickness, Net Res Thickness and Net Pay Thickness are 45ft., $25.5 \mathrm{ft}$., and $5.5 \mathrm{ft}$. respectively. Average Porosity, Average Water Saturation and Net-to-Gross ratio are $18 \%, 58 \%$ and 0.55 respectively. Similar depth map of R1 (Figure 12) shows that R2 is also in the most southerly compartment and from correlation; it extends to AY-1 well. To the north in the main XYZ compartment, the possibility of a hanging wall prospect exit.

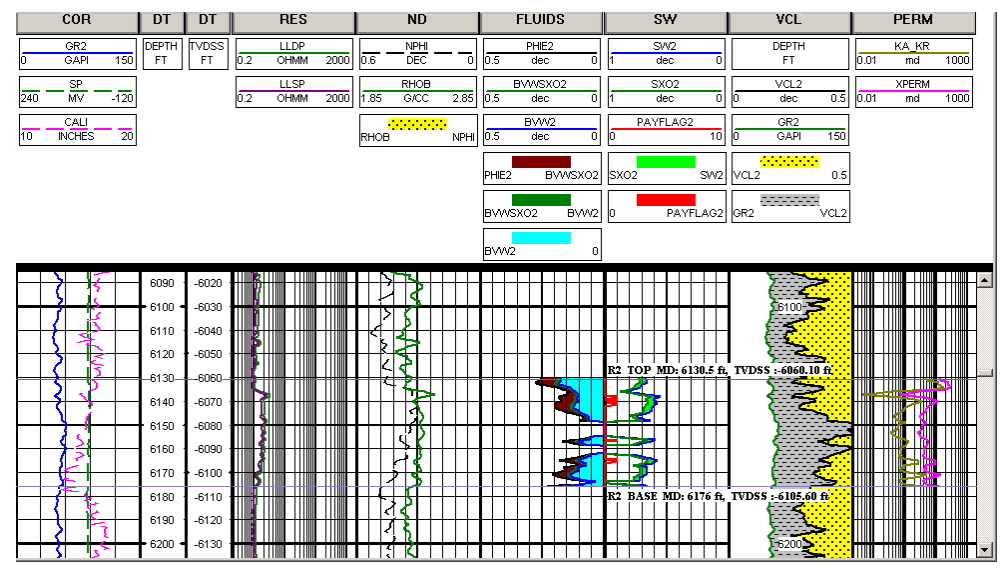

Fig. 11: Log Plot from R2 SAND. 


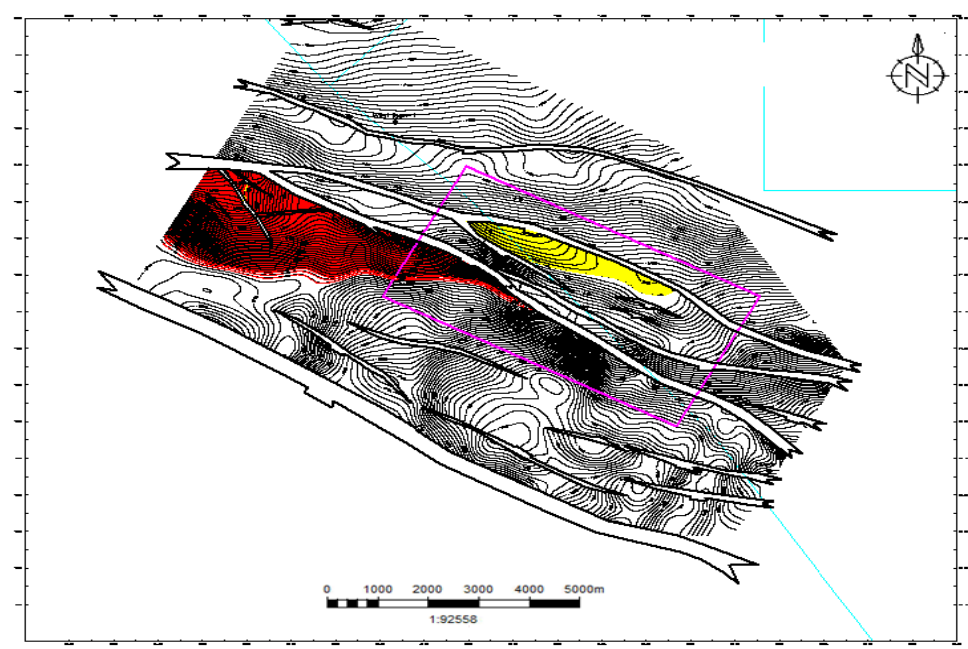

Fig. 12: R2 Sand Depth Structural Map.

The interpretation shows that part of this sand may have been clipped by the AY fault. The GR curve indicates a shaly reservoir with a low resistivity and a gross thickness of 19.5ft. It has an ODT at -6163.6ft TVDSS (Figure 17) and consists of oil (Figure 18). Other petrophysical parameters calculated are as follows:-

R3 Top is 6144.1ft (TVDSS) while R3 Base is 6163.6ft (TVDSS); Gross Thickness, Net Res Thickness and Net Pay Thickness are 19.5 ft., $13.70 \mathrm{ft}$., and $8 \mathrm{ft}$. respectively. Average Porosity, Average Water Saturation and Net-to-Gross ratio are 18\%, 53\% and 0.70 respectively.

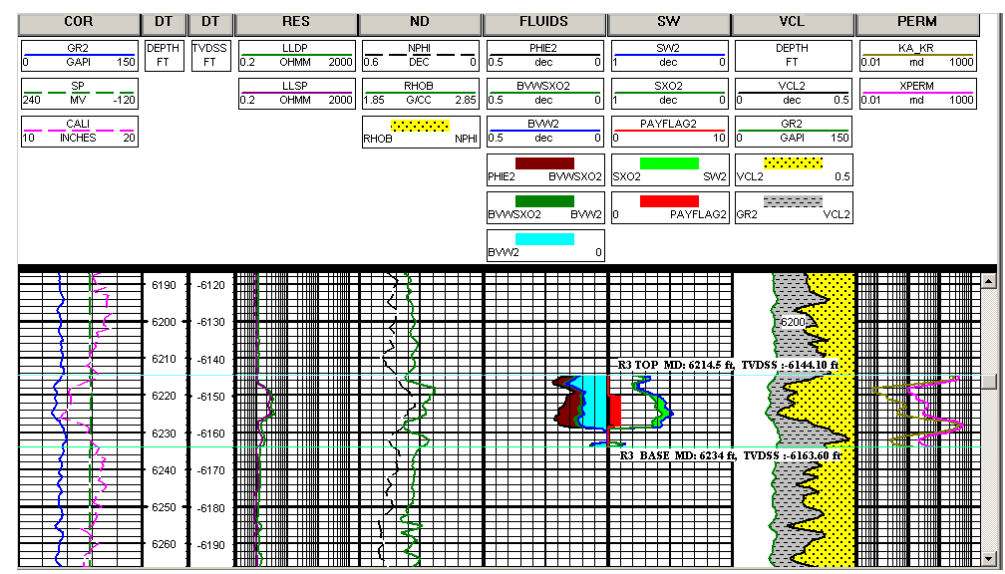

Fig. 13: Log Plot from R3 SAND.

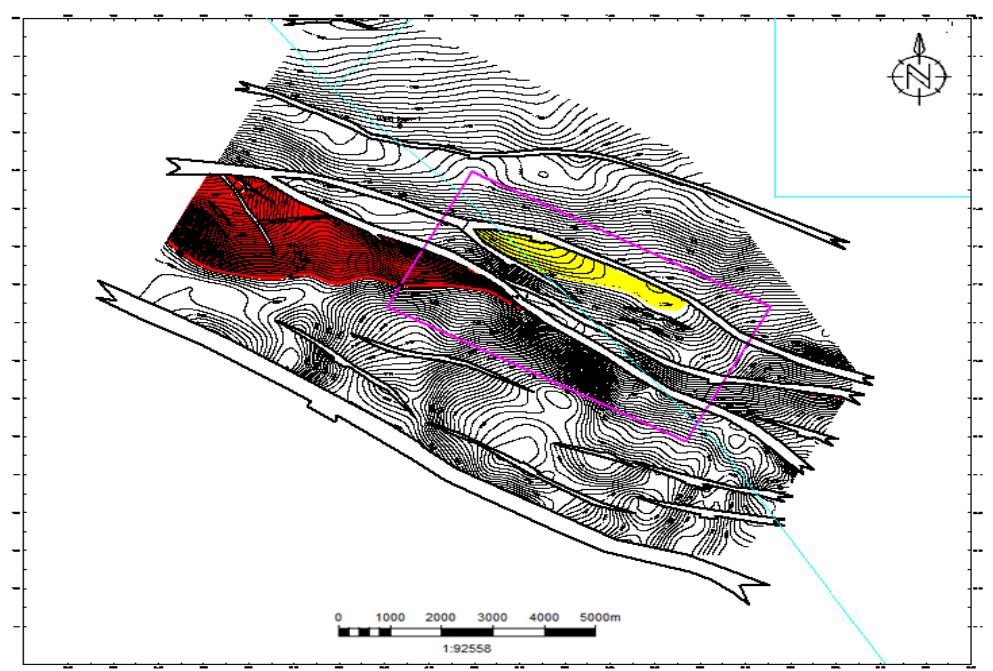

Fig. 14: R3 Sand Depth Structural Map.

\section{F Sand}

This very shaly sand is separated from the D5 sand by a $17 \mathrm{ft}$ of shale. it is the thickest reservoir with a gross thickness of $79.5 \mathrm{ft}$. The resistivity curve is fairly high which may be due to the shale present in the reservoir which contains oil (Figure 15). It has an Oil-DownTo (ODT) at 8798.6ft TVDSS Other petrophysical parameters calculated are as follows- The F Top is 8719.1ft (TVDSS)while F Base is 8798.6ft (TVDSS). Gross Thickness, Net Res Thickness and Net Pay Thickness is $79.5 \mathrm{ft}, 35.8 \mathrm{ft}$ and $11.5 \mathrm{ft}$ respectively. Average Porosity, AvERAGE Water Saturation and Net-to-Gross ratio is $17 \%, 46 \%$ and 0.45 respectively. 


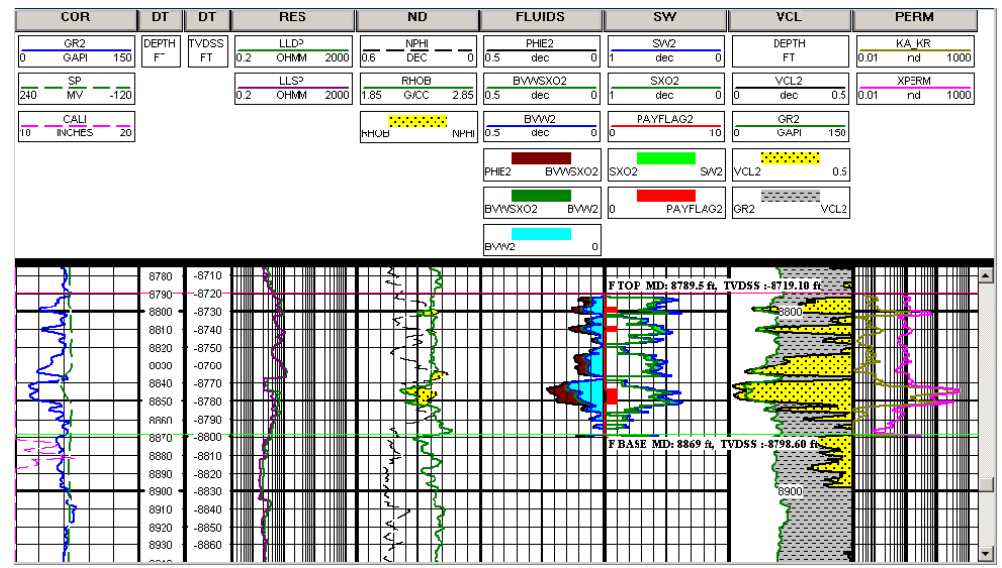

Fig. 15: Log Plot from F SAND

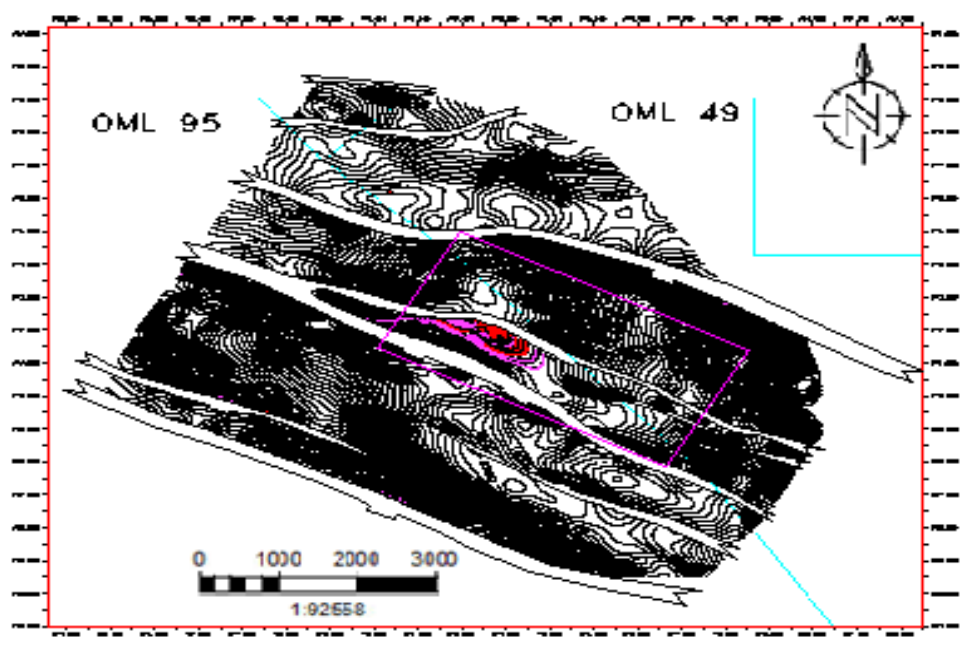

Fig. 16: F Sand Depth Structural Map.

\subsection{Prospects mapped}

A number of prospects have been identified and mapped in and around XYZ field. The prospective areas colour-filled yellow, have been shown in some of the reservoir maps above. Figure 17 shows the contacts map at maximum spill points for these prospects.

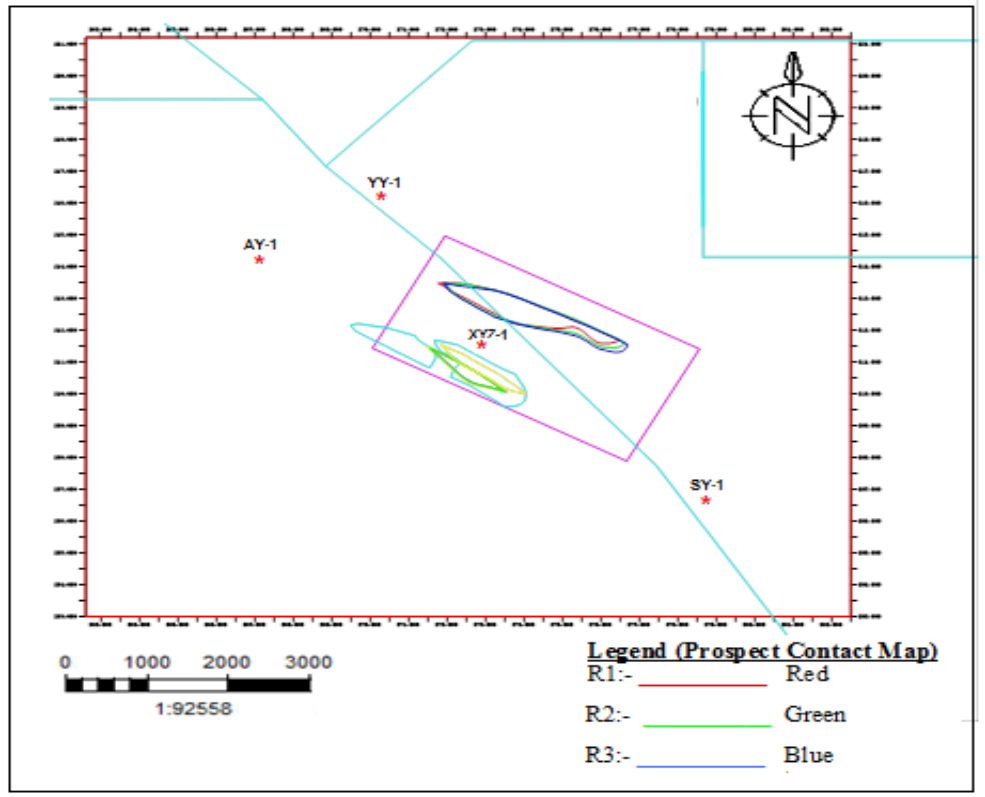

Fig. 17: Prospect Contacts Map.

The prospects identified are in two main areas:-

i) Hanging wall closures at shallow levels in the XYZ main fault block. The risk element is low given the unlikely occurrence of sand-to-sand juxtaposition given the high shale content and therefore good sealing in that interval. This prospect is shown on the $\mathrm{R}$ level maps. 
ii) Deeper levels within the main XYZ fault block. The risk element is the least when compared with 'i' and 'ii' above. This prospect is shown in F sand map.

\section{Conclusions and recommendations}

The following conclusions and recommendations can be drawn from the analysis and interpretation of XYZ field data:-

1) Within the main XYZ fault block, all the reservoir sands exhibits a bilobate accumulation separated by a saddle. Given that the western accumulation extends outside the field area.

2) From the shallow $R$ level maps generated, an anticlinal rollover structure which straddles into the area of study from the north was mapped. It is suspect that this structure may have been tested by the wells drilled on SY field. Given that this field is in production already, there is an urgent need to obtain information which will establish if unitization opportunity exists at these levels or not.

3) Similarly, the shallow R and deep F sands XYZ-1 extends and are downdip appraisal of AY field with no water contact established. Therefore there is opportunity for more oil downdip.

\section{Acknowledgements}

A lot of thanks are due to the two reviewers and the editor for their efforts and their valuable comments that have improved this paper. The authors express their kind thanks to Office of the Shell Professor of Geophysics, Obafemi Awolowo University, Ile Ife, Nigeria, for use of their facilities for data analysis.

\section{References}

[1] Alfred, D., Putra. E. and Schechter D. S., 2002, Transcending conventional log interpretation-a more effective approach for the Spraberry trend area: 2002 Naturally Fractured Reservoir Conference, Oklahoma City, Oklahoma, 3-4 June 2002, 8p.

[2] Allen, J. R. L., 1965, Late Quaternary Niger Delta, and adjacent areas-sedimentary environments and lithofacies: AAPG Bulletin, v. 49 , p. $547-$ 600. https://doi.org/10.1306/A663363A-16C0-11D7-8645000102C1865D.

[3] Avbovbo, A.A., 1978, Tertiary lithostratigraphy ofNiger Delta: AAPG Bulletin, v. 62, p. 295-306. https://doi.org/10.1306/C1EA482E-16C9-11D7$8645000102 \mathrm{C} 1865 \mathrm{D}$.

[4] Boyles, J.M. and A. J. Scott, 1981, Depositional systems, Upper Cretaceous Mancos Shale and Mesaverde Group, northwestern Colorado: Field trip guidebook, Rocky Mountain Section of SEPM, Part I, p. 1-82.

[5] Brown, L.F., and W.L. Fisher, 1977, Seismic-stratigraphy interpretation of depositionalsystems: examples from Brazil rift and pull-apart basins, in C. E. Payton, ed., Seismic stratigraphy-applications to hydrocarbon exploration: AAPG Memoir 26, p. 213-248.

[6] Bustin, R.M., 1988, Sedimentology and characteristics of dispersed organic matter in Tertiary Niger Delta: origin of source rocks in a deltaic environment: AAPG Bulletin, v. 72, p. 277-298. https://doi.org/10.1306/703C8C18-1707-11D7-8645000102C1865D

[7] Catuneanu, O., Willis, A.J., and Miall, A.D., 1998. Temporal significance of sequence boundaries: Sedimentary Geology, v 121, p. 157-178. https://doi.org/10.1016/S0037-0738(98)00084-0.

[8] Cole, R.D. and C.E. Mullen, 1992, Sedimentological reservoir characteristics of Tensleep Sandstone: Wyoming Geological Association 4th Annual Field Conference guidebook, p. 121-137.

[9] Coleman, J.M., and Prior D.B., 1981, Deltaic environments of deposition, in Scholle, P. A., and Spearing, D., eds., Sandstone depositional environments: AAPG Memoir 31, p. 139-178.

[10] Cook G., A. Chawathé, D. Larue, H. Legarre, and E. Ajayi, 1999, SPE 51892 Incorporating sequence stratigraphy in reservoir simulation: An integrated study of the Meren E-01/MR-05 sands in the Niger Delta, 1999 SPE Reservoir Simulation Symposium, Houston, Texas, 14-17 February 1999. 94 https://.doi.org/10.2118/51892-MS

[11] Doust, H., and E. Omatsola, 1990, Niger Delta, in J.D. Edwards and P.A. Santagrossi, Eds., Divergent/passive margin basins: AAPG Memoir 45, p. 201-238.

[12] Ebanks, W.J., Jr., 1987. Flow unit concept - integrated approach to reservoir description for engineering projects (abs.): AAPG 1987 Annual Meeting, Los Angeles, CA.

[13] Ejedawe, J.E. 1981, Patterns of incidence of oil reserves in Niger Delta basin: AAPG Bulletin, v. 65, p. 1574-1585. https://doi.org/10.1306/03B59620-16D1-11D7-8645000102C1865D.

[14] Ejedawe, J.E., Coker, S.J.L., Lambert-Aikhionbare, D.O., Alofe, K.B., and Adoh, F.O., 1984, Evolution of oil-generative window and oil and gas occurrence in Tertiary Niger Delta Basin: AAPG, v. 68, p. 1744-1751. https://doi.org/10.1306/AD46198F-16F7-11D7-8645000102C1865D.

[15] Ekweozor, C.M., and E.M. Daukoru, 1984, Petroleum source-bed evaluation of Tertiary Niger Delta-reply: AAPG Bulletin, v.68, p. 390-394. https://doi.org/10.1306/AD460A30-16F7-11D7-8645000102C1865D

[16] Evamy, B.D., J. Haremboure, P. Kamerling, W.A. Knaap, F.A. Molloy, and P.H. Rowlands, 1978, Hydrocarbon habitat of Tertiary Niger Delta: AAPG Bulletin, v. 64, p. 59-66. https://doi.org/10.1306/C1EA47ED-16C9-11D7-8645000102C1865D.

[17] Fisher, W. L., and J. H. McGowen, 1967, Depositional systems in the Wilcox Group of Texas and their relationship to occurrence of oil and gas: Transactions of the Gulf Coast Association of Geological Societies, v. 17, p. 105-125. https://doi.org/10.1306/5D25C217-16C1-11D7$8645000102 \mathrm{C} 1865 \mathrm{D}$.

[18] Frankl, E.J., and E.A. Cordy, 1967, The Niger Delta oil province- recent developments onshore and offshore: Mexico City, 7th World Petroleum Congress Proceedings, v. 1B, p. 195-209.

[19] Frey R. W and Pemberton S. G., 1984, Trace fossil facies models in R.G. Walker ed., Facies models; Geoscience Canada, p. 189-208.

[20] Galloway, W.E., 1998, Siliciclastic slope and base-of-slope depositional systems: component facies, stratigraphic architecture, and classification: AAPG Bulletin, v. 82, p. 569-595.

[21] Haack, R.C., Sundararaman, P., and Dahl, J., 1997, Niger Delta petroleum system, in, extended abstracts, AAPG/ABGP Hedberg Research Symposium, Petroleum Systems of the South Atlantic Margin, November 16-19, 1997, Rio de Janeiro, Brazil.

[22] Jev B. I., C., H. Kaars-Sijpesteijn, M. P. A. M. Peters, N. L. Watts and J. T. Wilkie, 1993, Akaso Field, Nigeria: Use of integrated 3-D seismic, fault slicing, clay smearing, and RFT pressure data on fault trapping and dynamic leakage. AAPG Bulletin, v. 77, p 1389-1404. https://doi.org/10.1306/BDFF8EA2-1718-11D7-8645000102C1865D

[23] Kaplan, A., Lusser, C.U., Norton, I.O., 1994, Tectonic map of the world, panel 10, scale 1:10,000,000: AAPG, Tulsa, Oklahoma.

[24] Kerans C and S.W. Tinker, 1997, Sequence Stratigraphy and Characterization of Carbonate Reservoirs: SEPM Short Course Notes No. 40 129p. https://doi.org/10.2110/scn.97.40.

[25] Knox, G.J., and E.M. Omatsola, 1989, Development of the Cenozoic Niger delta in terms of the "escalator regression" model and impact on hydrocarbon distribution, in W.J.M. van der Linden et al., eds., 1987, Proceedings, KNGMG Symposium on Coastal Lowlands, Geology, Geotechnology: Dordrecht, Kluwer Academic Publishers, p. 181-202. https://doi.org/10.1007/978-94-017-1064-0_12. 
[26] Lambert-Aikhionbare, D.O. 1982, Relationship between diagenesis and pore fluid chemistry in Niger delta oil-bearing sands: Journal of Petroleum Geology, v. 4, p. 287-298. https://doi.org/10.1111/j.1747-5457.1982.tb00540.x.

[27] McAfee 1994: Sedimentological analysis of core from Well Meren-75 Nigerian Niger Delta Complex. Chevron Nigeria Limited, Lagos, Nigeria, Unpublished.

[28] McCubbin, D.G., 1982. Barrier Island and strand-plain facies. in P.A. Scholle and D. Spearing eds., Sandstone depositional environments. AAPG Memoir 31, p. 247-279.

[29] McHargue, T., Diedjomahor J., Arowolo I., Hobbet R., and V. Onyia, 1993, Abstract, Application of sequence stratigraphy to neritic sediments of the Niger Delta, AAPG International Conference, The Hague, Netherlands October 17-20, 1993 p. 1647. https://doi.org/10.1306/BDFF8330-171811D7-8645000102C1865D.

[30] Mitchum, R.M. Jr., 1977, Seismic stratigraphy and global changes of sea-level, Part II Glossary of terms used in seismic stratigraphy. in C.E. Clayton ed., Seismic stratigraphy -application to hydrocarbon exploration: AAPG Memoir 26, p. 49-212.

[31] Moslow, T. F., and Pemberton, S. G., 1988, An integrated approach to the sedimentological analysis of some Lower Cretaceous shoreface and delta front sandstone sequences, in D. P. James, and D. A. Leckie, eds., Sequences, stratigraphy, sedimentology: surface and subsurface: Canadian Society of Petroleum Geologists Memoir, v. 15, p. 373-386.

[32] Moslow, T. F., and Tillman, R. W., 1986, Sedimentary facies and reservoir characteristics of Frontier Formation sandstones, southwestern Wyoming, in C. W. Spencer and R. F. Mast, eds., Geology of tight gas reservoirs: AAPG Studies in Geology 24, p. 271-311.

[33] Oomkens, E., 1974, Lithofacies relations in late Quaternary Niger Delta complex: Sedimentology, v. 21 , p. 195-222. https://doi.org/10.1111/j.1365-3091.1974.tb02056.x.

[34] Orife, J.M., and A. A. Avbovbo, 1981, Stratigraphic and unconformity traps in the Niger Delta (abs.): AAPG Bulletin, v. 65, p. 967. https://doi.org/10.1306/2F91A0F7-16CE-11D7-8645000102C1865D.

[35] Petroconsultants, 1996, Petroleum exploration and production database: Houston, Texas, Petroconsultants, Inc., [database available from Petroconsultants, Inc., P.O. Box 740619, Houston, TX 77274-0619]. 